\title{
Permeability of Paricá (Schizolobium amazonicum herb.) Wood Species from the Amazon Region
}

\author{
Laurenn Borges de Macedo ${ }^{1}$, Diego Henrique de Almeida ${ }^{1}$, Carlito Calil Neto ${ }^{1}$, Luciano Donizeti Varanda ${ }^{2}$, \\ André Luis Christoforo ${ }^{3, *}$, Carlito Calil Junior ${ }^{1}$, Francisco Antonio Rocco Lahr ${ }^{1}$ \\ ${ }^{1}$ Department of Structural Engineering, Engineering School of São Carlos (EESC/USP), São Carlos, 13566-590, Brazil \\ ${ }^{2}$ Department of Material, Engineering School of São Carlos (EESC/USP), São Carlos, 13566-590, Brazil \\ ${ }^{3}$ Centre for Innovation and Technology in Composites - CITeC, Department of Civil Engineering, Federal University of São Carlos, \\ São Carlos, 13565-905, Brazil
}

\begin{abstract}
Paricá (Schizolobium amazonicum Herb.), is a native species from Amazon region, with very susceptible wood to xylophagous agents attacks. Therefore, to know the permeability of this species is information to define the chemical treatment suitable for the durability of this wood in use. For this study, it sawed wood from planted areas of the amazon region was used. It is possible to determine the permeability with the aid of proper equipment. The specimens, used in this research, were obtained randomly from pieces, 6 specimens for each one of the fluids tested: atmospheric air, distilled water and CCA chemical preservative. The value of atmospheric air permeability was $504.15 \mathrm{~cm}^{3} / \mathrm{cm} . \mathrm{atm} . \mathrm{s}$ with variation coefficient of $7.78 \%$. For distilled water, the permeability and the variation coefficient were $10.84 \mathrm{~cm}^{3} / \mathrm{cm}$.atm.s and $23.16 \%$, respectively. Regarding the CCA, the permeability was $228.69 \mathrm{~cm} / \mathrm{cm} . a t m . s$ and the variation coefficient $61.97 \%$.
\end{abstract}

Keywords Physical properties, Permeameter, treatability of wood

\section{Introduction}

Wood has been used for various purposes over the centuries for being a material with singular characteristics [1]. Every day, the development of technologies in the forest sector have enabled increase in the potential uses of this raw material due to improvements in their physical, chemical and mechanical properties. In Brazil, the Amazon region is considered a potential area of investment in the forest sector, since it offers good demand of species with large variability of properties and possibilities for several uses. However, even taking in account this favorable aspect of the region, the lack of knowledge about the properties of most species and their performance under some usage conditions is still an obstacle for the adequate application of wood.

From the 80s, some government initiatives have encouraged the characterization of native species. Various works in this direction have been conducted since then and, hereupon, is verified a possible reduction in the use of consecrated species, making possible a gradual decrease of deforested areas $[2,3]$.

The Paricá (Schizolobium amazonicum Herb.), species of the Caesalpinaceae family and originally from the northern

* Corresponding author:

alchristoforo@yahoo.com.br (André Luis Christoforo)

Published online at http://journal.sapub.org/ijme

Copyright (C) 2014 Scientific \& Academic Publishing. All Rights Reserved region of Brazil, presents a straight stem with a low incidence of nodes. The wood of this species has a yellowish-white color, with good visibility of growth rings and perceptible distinction between heartwood and sapwood. According to [4], most of the biomass produced by the trees of this species is concentrated in the stem. In accordance with [5], the Paricá has a basic density varying from 0.3 $\mathrm{g} / \mathrm{cm}^{3}$ to $0.62 \mathrm{~g} / \mathrm{cm}^{3}$, which provides good workability of the species of wood.

The low incidence of defects in wood, the high price in internal and external market and its easy processing and excellent workmanship makes Paricá a species of great potential for several uses [6]. Paricá has been employed since for matchsticks manufacturing to the production of doors, plywood, particleboard, glulam timber and concrete formwork. Paricá presents good potential for commercial plantations, agroforestry and reforestation of degraded areas because it has a rapid development and a good performance both in homogeneous cultures and in consortium [7].

Due to its low extractives content, compared to other tropical species, this species can be very susceptible to attack by xylophagous agents [8]. Therefore, the study of its permeability becomes of great importance to ensure that the preservative treatment can be made properly, making it possible to prolong their durability and, consequently, increasing their usability. From a commercial viewpoint, the use of biocides, also known as wood preservatives, is the most beneficial. The preservative treatment implies an 
increase of the initial cost, however, due to greater durability of wood over the period of use, the cost is diluted to the point of being more advantageous compared to untreated wood [9].

The permeability of the wood is determined by the facility with which certain fluid through a porous solid because of the actions of a pressure gradient, obeying Darcy's law $[10,11]$.

Property directly related to the treatability of wood, permeability is greatly influenced by the chemical and physical composition of the material, as well, by the flow regime of the fluid used, the permeability can be in the longitudinal direction of the wood in the order of more than 1000 times higher than the same greatness as the tangential or radial direction [12]. Still according to the same author, to eliminate the influence caused by the fluid during the determination of this property can use the specific permeability. Thus, according to [13-15], the values obtained of the permeability are independent of the fluid and will only be a function of the size and number of openings of the anatomical characters of the wood structure.

Because of the growing demand for the use of the species Paricá, the need of to prove greater durability of the species for structural purposes, the need of to provide greater durability of the species for structural purposes, through the chemical treatment and, the possibility of its use in the production of GLT, this study aimed to determine and compare permeability of this species of wood in relation to fluids like air, distilled water and the chromated copper arsenate chemical preservative (CCA).

\section{Material and Methods}

For the present study Paricá wood obtained from the National University of Pará (UFPA), Brazil was used.

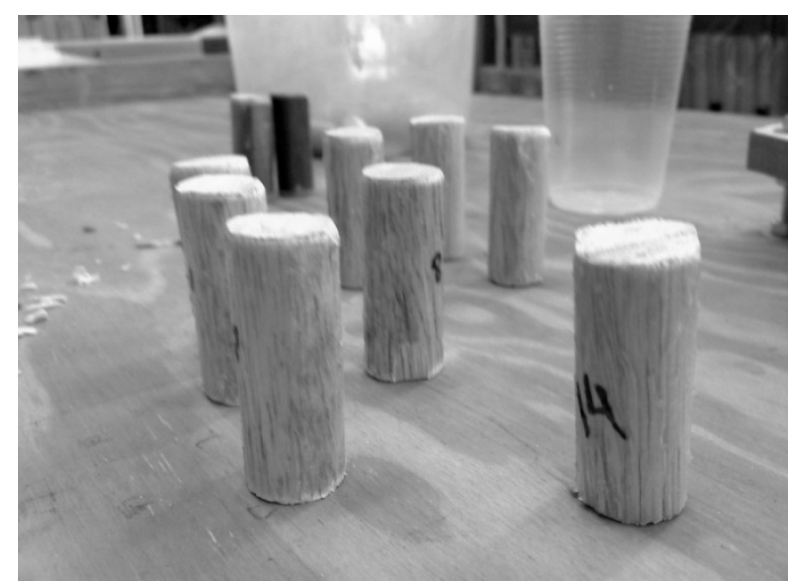

Figure 1. The specimens sealed with a resin based on oil castor bean

The specimens were obtained from pieces in equilibrium ambient moisture with thicknesses ranging from 35 to 40 $\mathrm{mm}$, width of approximately $150 \mathrm{~mm}$ and a length of $2.5 \mathrm{~m}$, randomly chosen from a homogeneous lot. The pieces were lathed to achieve the appropriate size for testing in the
Laboratory of Wood and Timber Structures (LaMEM) of School of Engineering of São Carlos (EESC) of University of São Paulo (USP) to obtain samples of cylindrical shapes. 18 specimens with longitudinal length ranging from 48.61 to $51.73 \mathrm{~mm}$ and the diameter 18.77 to $21.74 \mathrm{~mm}$ were used. 6 specimens were used to evaluate the permeability of the wood for each type of fluid analyzed. To ensure the fluid flow only in the desired longitudinal direction (parallel to the fibers of the wood), the specimens were sealed in its lateral direction with a resin based on oil castor bean. The resin was easily applied using a brush, with rectilinear motion, with the curing time of approximately 72 hours (Figure 1).

For conducting permeability tests a vacuum pump was used with DUO-SEAL manometer of spring $760 \mathrm{mmHg}$ coupled to a permeameter, fluids used during testing were atmospheric air, distilled water and CCA chemical preservative.

For permeability tests in atmospheric air, the permeameter has three rotameters connected in series, on scales of sequence 10 to $100 \mathrm{l} / \mathrm{h}, 10$ to $180 \mathrm{l} / \mathrm{h}$ and 100 to $1100 \mathrm{l} / \mathrm{h}$. These rotameters have the purpose of measuring the air flow through the specimens, which were engaged in a device where the flowmeters were connected at one end of the sample and in the other vacuum was applied. During the test, the air flow in the specimen, the time in minutes in which the flow became constant and the pressure applied by the vacuum pump (Figure 2) were recorded.

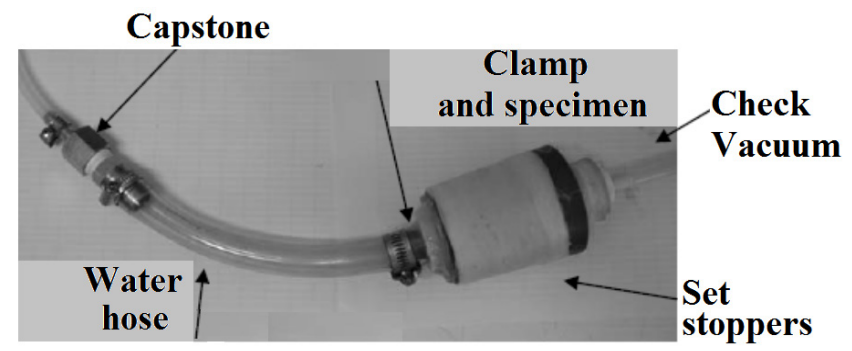

Figure 2. Equipment for determining the air flow. Source: [11]

To calculate the permeability to gas flow (compressible fluid), the gas expansion and resulting changes in gradient along the kind were considered. The Darcy equation for gas flow is designated by Equation 1.

$$
K_{g}=\frac{V \cdot L \cdot P}{t \cdot A \cdot \Delta P \cdot P_{1}}
$$

From Equation $1, K_{g}$ denotes the permeability to gas in $\mathrm{cm}^{3}$ (gas)/ (cm.atm.seconds); $V$ is the volume of gas flow through the specimen in $\mathrm{cm}^{3}$ (gas); $L$ is the length of the specimen in the flow direction, in $\mathrm{cm} ; P$ is the pressure at which the gas volume is measured in atm; $t$ is time in seconds; $A$ is the cross sectional area of the specimen in $\mathrm{cm}^{2} ; \Delta P$ is the difference in pressure, in atm, and $P_{l}$ is the average pressure in the specimen, in atm.

In tests with liquid, the same permeameter was used, however, with an adaptation. The rotameters were connected to the system a burette with a $25 \mathrm{ml}$ (Figure 3). For this test, it was made a set of corks where the specimen fit with a face 
under vacuum through a conical glass joint and the other side connected to a burette containing the liquid (Figure 3 ). The time it takes for a volume of $25 \mathrm{ml}$ of liquid crosses the specimen (by vacuum) was measured using a digital chronometer. The value of the maximum pressure reached during this process was also recorded.

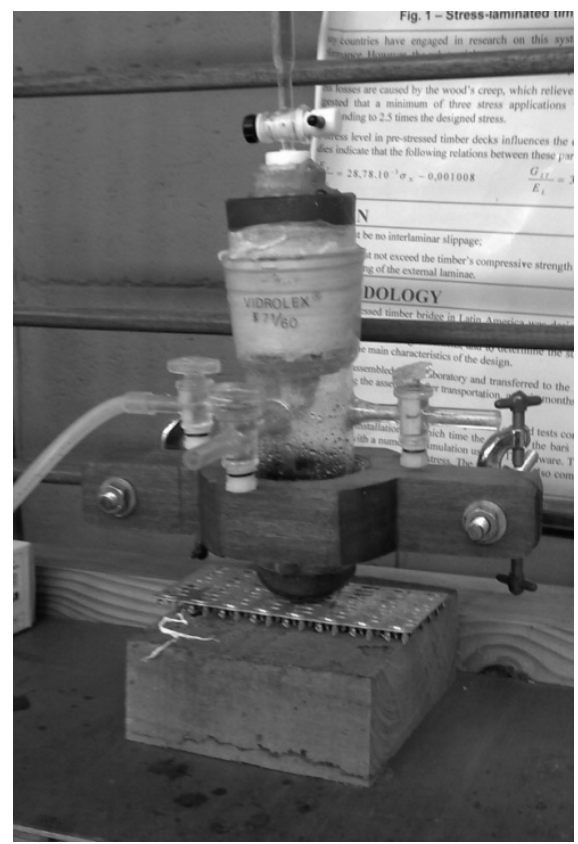

Figure 3. Equipment for measuring the permeability to liquid

To calculate the permeability of liquid, the steady state flow with the Darcy equation is written for liquid (Equation 2).

$$
K_{g}=\frac{152 \cdot Q \cdot L \cdot P_{a}}{A \cdot \Delta P_{m} \cdot\left(2 \cdot P_{a}-\Delta P_{m}\right)}
$$

From Equation 2, Q is the flow rate of the gas in $\mathrm{cm}^{3} /$ second, as determined for the calibration graph supplied with the rotameter, $\mathrm{P}_{\mathrm{a}}$ is the atmospheric pressure in $\mathrm{cmHg}$ and $\Delta \mathrm{P}_{\mathrm{m}}$ is the initial pressure gauge reading, in $\mathrm{cmHg}$.

\section{Results and Discussions}

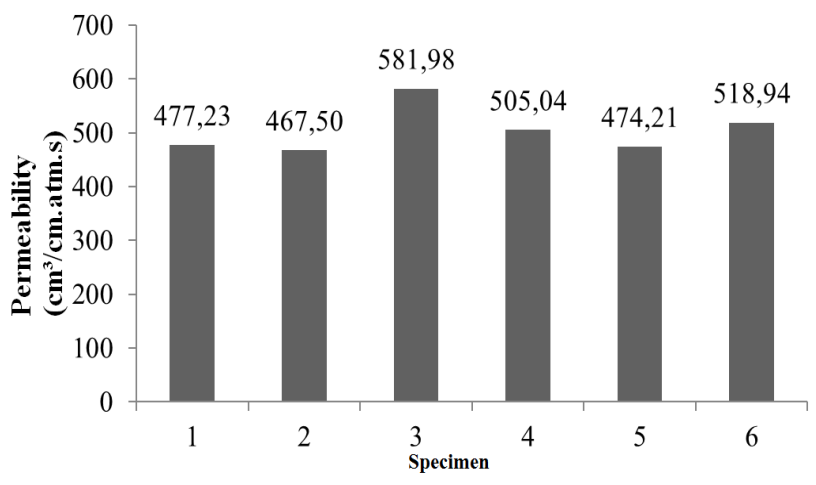

Figure 4. Paricá permeability of atmospheric air

The average value of permeability of atmospheric air in the wood Paricá was $504.15 \mathrm{~cm}^{3} / \mathrm{cm}$.atm.s, with a coefficient of variation of $7.78 \%$. Figure 4 illustrates the bar graph with the permeability values obtained for each specimen tested.

For liquid permeability, the variation coefficient was higher than that found in atmospheric air permeability, being the Paricá average permeability to distilled water in the amount of $10.84 \mathrm{~cm}^{3} / \mathrm{cm}$.atm.s, with a coefficient of variation of $23.16 \%$. The average value of permeability of chemical preservative CCA was $228,69 \mathrm{~cm}^{3} / \mathrm{cm}$.atm.s, presenting coefficient of variation of $61.97 \%$.

Figure 5 illustrates the results of water permeability and CCA for each specimen tested.

The obtained value of the air permeability of the Paricá wood was much higher than that found by [13] in his research with wood Amapá (Brosimum parinarioides Ducke) and Faveira (Parkia gigantocarpa Ducke), that presented the values for the gas permeability of 65.42 and 121.54 $\mathrm{cm}^{3} / \mathrm{cm}$.atm.s respectively.

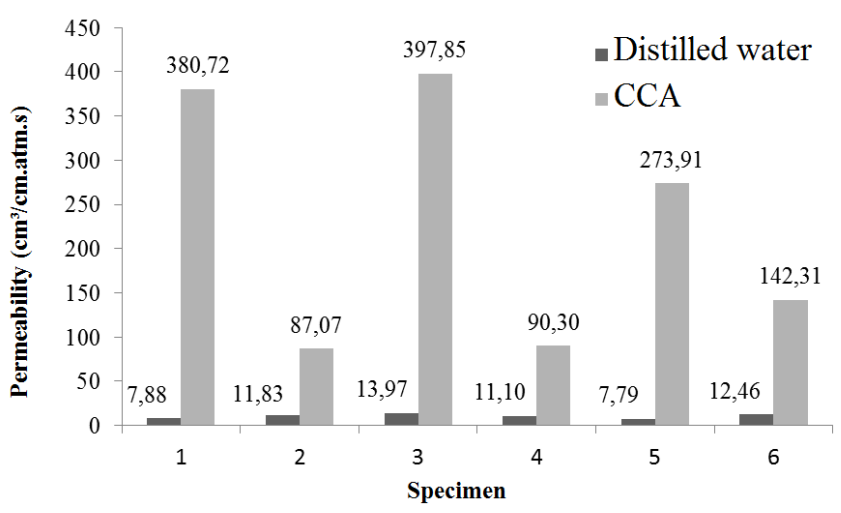

Figure 5. Permeability to distilled water and CCA by the Paricá

However, coefficients of variation found by the same author for these species were higher than found for Paricá, in the order of $17 \%$ for Amapá and 58\% for Faveira.

In his research, [11] found average values of air permeability of specimens taken from the sapwood of Corymbia citriodora and Eucalyptus grandis equal to 611.91 and $681.53 \mathrm{~cm}^{3} / \mathrm{cm}$. atm.s, respectively. Regarding the coefficient of variation, sampling of Corymbia citriodora woods presented coefficient of $4.37 \%$, lower than Paricá, unlike the Eucalyptus grandis, which showed a coefficient of variation of $10.93 \%$. For samples taken from the heartwood of Eucalyptus grandis, the value of permeability $\left(24.58 \mathrm{~cm}^{3} /\right.$ cm.atm.s) was much lower than the value obtained for Paricá, however, with coefficient of variation (16.78\%) superior. The same author also tested the value of the same fluid permeability for Pinus elliottii, which was 141.71 $\mathrm{cm}^{3} / \mathrm{cm}$.atm.s, lower than that found for Paricá, with coefficient of variation (10.19\%) higher than Paricá.

In his studies, [11] found average values for distilled water permeability of Corymbia citriodora sapwood equal to $346.86 \mathrm{~cm}^{3} / \mathrm{cm}$.atm.s and $470.57 \mathrm{~cm}^{3} / \mathrm{cm}$.atm.s for Eucalyptus grandis, much higher than the values found for the wood Paricá, with coefficient of variation equal to $19.28 \%$ and $25.90 \%$, respectively, very close to the coefficient of variation obtained for Paricá. For Eucalyptus 
grandis, core permeability reached $0.42 \mathrm{~cm}^{3} / \mathrm{cm} . \mathrm{atm} . \mathrm{s}$ (inferior to Paricá) with coefficient of variation $61.14 \%$ (superior). For the heartwood of Pinus elliottii, permeability and coefficient of variation were $5.46 \mathrm{~cm}^{3} / \mathrm{cm}$.atm.s and $46.59 \%$, respectively, being lower permeability than Paricá and the coefficient of variation superior.

In their studies, [10] found lower values than the Paricá for permeability to distilled water of Faveira wood and Amapá wood, being in the order of 2.01 and $2.21 \mathrm{~cm}^{3} / \mathrm{cm}$.atm.s, respectively. The coefficients of variation were larger than Paricá, $76 \%$ to Amapá and $93 \%$ to Faveira.

According to [9-11], the major influence factor in the liquid permeability of wood is the fluid viscosity. Considering Poiseuille equation as applicable here, permeability shows itself inversely proportional to viscosity. The viscosity of distilled water is about 1 centipoise (cp) at $25^{\circ} \mathrm{C}$, and according to the manufacturer preservative, the solution viscosity of the CCA is predominantly same as water, because of its aqueous composition, factor that does not explain why the permeability of Paricá wood to the CCA be more than twenty times higher than the value of the permeability to distilled water.

The fact of the specimens have been removed from randomly chosen tables can be considered an explanation for the higher value of permeability to CCA in relation to distilled water of wood studied. It is sufficient that just the specimens used in the tests of water permeability had been removed from the area near the tree heartwood zones, and specimens for testing the permeability to CCA were coming from regions of sapwood, difference between such values would already be explained. Also, one of very important factors which are not known in this study are possible occurrences in the internal structure of the wood, for example, the presence of obstructions in the pores of the wood caused by external injuries possible that the tree may have suffered throughout its existence, which could significantly impede the flow of fluid through the wood. In addition, [8] describes that the tiles are similar to membranes balls which enter in the vessel from the parenchymal cells by pairs of adjacent pits. The tiles are found at the heartwood of certain species of wood and can obstruct fully or partially the lumen of the vessels. Thus, the tiles, gums and other deposits can impede or significantly decrease the permeability of the heartwood of many dicotyledonous woods.

\section{Conclusions}

The atmospheric air permeability was greater than the liquid permeability due to the greatest ease of displacement of the gaseous fluid. The permeability to liquid chemical preservative CCA was about ten times higher in comparison to distilled water, and, depending on viscosity, were expected approximate values. Factors that contributed to these results consisted in the removal of specimens in heartwood area of the tree and coming from regions of sapwood. Due to the good permeability to liquid and atmospheric air, the results obtained demonstrate the feasibility of using wood Paricá (Schizolobium amazonicum Herb.) for processes that the displacement of fluid through the wood is necessary, as treatments and other applications.

\section{ACKNOWLEDGEMENTS}

The authors thank the Laboratory of Wood and Timber Structures (LaMEM) Department of Structures (SET) of School of Engineering of São Carlos (EESC), University of São Paulo (USP) by the possibility of doing this work, and also the National University of Pará (UFPA), by donating of wood used in tests.

\section{REFERENCES}

[1] Christoforo, A. L.; Ribeiro Filho, S. L. M.; Panzera, T. H.; Rocco, F. A. L. Metodologia para o cálculo dos módulos de elasticidade longitudinal e transversal em vigas de madeira de dimensões estruturais. Ciência Rural (UFSM. Impresso), v. 43, p. 610, 2013.

[2] Barbosa, R. I.; Ferreira, C. A. C. Densidade básica da madeira de um ecossistema de "campina" em Roraima, Amazônia Brasileira. Acta Amazonica, Manaus, v. 34, n 4, p. 587-591, 2004.

[3] Paula, J. E. Caracterização anatômica da madeira de sete espécies da amazônia com vistas à produção de energia e papel. Acta Amazonica, Manaus, v. 33, n. 2, p. 243-262, 2003.

[4] Zangiácomo, A. L. Emprego de espécies tropicais alternativas na produção de elementos estruturais de madeira laminada colada. 2003, 89 p. Tese (Doutorado em Engenharia de Estruturas) - Universidade de São Paulo, São Carlos.

[5] Rondon, E. V. Produção de biomassa e crescimento de árvores de Schizolobium amazonicum (Huber) Ducke sob diferentes espaçamentos na região de mata. Revista Árvore, Viçosa, v.25, n.5, p. 573-176, 2002.

[6] Rojas, M. R.; Martina, A. M. S. Manual de identificación de especies forestales de la subreregión andina. Lima: OIT, 1996. $291 \mathrm{p}$.

[7] Almeida, D. H.; Macedo, L. B.; Scaliante, R. M.; Macedo, A. N.; Calil Junior, C. Madeira laminada colada (MLC) da espécie Paricá. Madeira: Arquitetura e Engenharia, v. 12, p. 71-82, 2011.

[8] Scaliante, R. M.; Almeida, D. H.; Macedo, L. B.; Macedo, A. N.; Calil Jr, C. Ensaio de fluência e de compressão paralela às fibras para situações da madeira à umidade de equilíbrio e saturada. Madeira: Arquitetura e Engenharia, v. 12, p. 19-30, 2011.

[9] Vidaurre, G. B. Caracterização anatômica, química e físico-mecânica da madeira de Paricá (Schizolobium amazonicum) para a produção de energia e polpa celulósica. 2010, 88 p. Tese (Doutorado em Ciência Florestal) Universidade Federal de Viçosa, Viçosa.

[10] Rezende, J.L.P.; Nascimento, A.M.; Oliveira, A.D.; Análise 
econômica da preservação de madeiras. Imprensa Universitária, Universidade Federal de Viçosa, Minas Gerais, 1993.

[11] Siau, J. F. Flow in wood. Syracuse: Syracuse University Press, 1917. 131p.

[12] Jankowsky, I. P. Os creosotos na preservação de madeiras. Revista IPEF, Piracicaba, n. 34, p. 5-14, 1986.

[13] Lepage, E. S. Preservativos e sistemas preservativos. In: LAPAGE, E. S. (Coord.) Manual de preservação de madeiras. São Paulo: IPT, 1986, v.1, p.279-342.
[14] Silva, M. R. Determinação da permeabilidade em madeiras brasileiras de florestas plantadas. 2007, 137 p. Dissertação (Mestrado em Ciências e Engenharia de Materiais) Universidade de São Paulo, São Carlos.

[15] Baraúna, E. E. Caracterização da permeabilidade das madeiras de Amapá (Brosimum parinarioides Ducke) e Faveira (Parkia gigantocarpa Ducke) oriundas da floresta amazônica. 2009. 78 p. Tese (Doutorado em Ciência e Tecnologia da Madeira) - Universidade Federal de Lavras, Lavras. 